\title{
KEDUDUKAN HUKUM PEMEGANG POLIS PADA PERUSAHAAN ASURANSI YANG DINYATAKAN PAILIT
}

\author{
Ni Kadek Vikka Ayu Swandewi, Ni Luh Made Mahendrawati, I Putu Gede Seputra \\ Fakultas Hukum Universitas Warmadewa, Denpasar-Bali, Indonesia \\ vikkaayuswandewi@gmail.com, mademahendrawati@gmail.com,gamyongputu@gmail.com
}

\begin{abstract}
Abstrak
Di era globalisasi ini, asuransi sudah dianggap sebagai kebutuhan pokok yang mana merupakan kebutuhan manusia akan rasa aman. Asuransi adalah bentuk dari manajemen risiko yang dibentuk dengan tujuan untuk menghindari kemungkinan- kemungkinan dari terjadinya resiko kerugian yang tidak tentu. Penelitian ini bertujuan menelaah kedudukan hukum Pemegang Polis sebagai kreditur pada Perusahaan Asuransi dan mengungkapkan perlindungan hukum pemegang polis pada perusahaan asuransi yang dinyatakan pailit. Penelitian ini menggunakan metode penelitian norrnatif dikarenakan masih terdapat konflik norma, dengan dengan pendekatan Perundang-undangan. data bersurnber pada pendapat para sarjana hukum dan Undangundangan. Adapun sumber data yaitu data primer dan sekunder yang diperoleh melalui pencatatan dan dokumentasi, selanjutnya data diolah menggunakan interpretasi dan deskriptif. Berdasarkan Undang-undang Kepailitan dan PKPU Pasal 1 angka 2 Kreditor adalah pihak yang memiliki piutang karena perjanjian atau Undang-undang yang dapat ditagih di muka jasa. Dalam rangka perlindungan hukum pihak pemegang polis, Undang undang Perasuransian telah mengatur adanya lembaga penjamin polis yang mana tujuan dibentuknya program penjamin polis ialah untuk menjamin pengernbalian sebagian atau seluruh hak pemegang polis. Dalam pailit dan dilikuidasi suatu Perusahaan Asuransi diharapkan curator memperhatikan hak Pemegang Polis dalam mendapatkan ganti rugi dari harta pailit Perusahaan Asuransi.
\end{abstract}

Kata Kunci : Asuransi, Kedudukan Hukum, Pailit

\begin{abstract}
In this era of globalization, insurance has been considered as a basic need which is a human need for security. Insurance is a form of risk management that is formed with the aim of avoiding the possibility of an uncertain risk of loss. This study aims to examine the legal position of policyholders as creditors in insurance companies and to reveal the legal protection of policyholders in insurance companies that are declared bankrupt. This study uses a normative research method because there is still a conflict of norms, with the approach to legislation. The data is sourced from the opinions of legal scholars and data law. The data sources are primary and secondary data obtained through recording and documentation, then the data is processed using interpretation and descriptive. Based on the Bankruptcy Law and PKPU Article 1 number 2, creditors are parties who have receivables due to agreements or laws that can be collected in advance of services. In the context of the legal protection of the policyholder, the Insurance Act has regulated the existence of a policy guarantor institution in which the purpose of the establishment of a policy guarantee program is to guarantee the return of part or all of the rights of the policyholder. In the bankruptcy and liquidation of an Insurance Company, it is expected that the curator will pay attention to the right of the Policy Holder to obtain compensation from the bankruptcy assets of the Insurance Company.
\end{abstract}

Keywords: Insurance, Legal Position, Bankruptcy

\section{PENDAHULUAN}

Pada era globalisasi ini, asuransi sudah dianggap sebagai solusi yang bisa membantu kebutuhan manusia akan rasa aman, dan terlindungi terhadap kemungkinan-kemungkinan dari risiko kerugian di kemudian hari. Asuransi ialah bentuk dari manajemen risiko yang dibentuk dengan tujuan mencegah perkiraan-perkiraan dari terwujudnya risiko kesusahan yang belum menentu. Pertanggungan dapat didefinisikan sebagai transfer adil atas risiko suatu kerugian, dari satu entitas ke entitas lain menggunakan jalan memecah bahaya dalam hal pendanaan ditengah semua insentif (Hartono, S. R. 2001)

Tujuan asuransi ialah untuk memberikan jaminan untuk menutup resiko ataupun kesusahan 
yang mungkin ditanggung dari terwujudnya kejadian yang dialami oleh yang berkaitan (Novi et al., 2016). Dalam asuransi memiliki unsur-unsur yang penting salah satunya adalah unsur ganti rugi, unsur ini merupakan unsur yang paling penting, tetapi tidak melintas selaras dengan pejabat matamata pertanggungan, yaitu mengikat pribadi oleh kesepakatan-kesepakatan pertanggungan. Pejabat mata-mata pertanggungan adalah pihak yang memiliki wewenang untuk memegang perjanjian antara pihak tertanggung dan pihak penanggung (Sabrie, 2011). Pemegang polis juga dicantumkan namanya pada surat perjanjian tersebut, di Indonesia usaha perasuransian diatur dengan Undang-undang Nomor 2 Tahun 1992 tentang Usaha Perasuransian saat ini telah digantikan dengan Undang-undang Nomor 40 Tahun 2014 tentang Perasuransian. Keberadaan undang-undang sebagai suatu dasar hukum dalam halnya melaksanakan kegiatan atau usaha perasuransian diharapkan mampu membuat usaha perasuransian di Indonesia berjalan lebih baik, serta dapat meningkatkan perlindungan kepentingan rnasyarakat pengguna dari jasa asuransi.

Namun hal tersebut akan berbeda jika Perusahaan Asuransi yang bersangkutan mengalami pailit. Kepailitan merupakan suatu proses dimana seorang debitur mempunyai kesulitan keuangan untuk membayarkan utang, sehingga debitur dinyatakan pailit oleh Pengadilan Niaga dikarenakan debitur tersebut tidak dapat membayar hutangnya. Kepailitan berdasarkan Pasal 1 angka 1 Undangundang Nomor 37 Tahun 2004 tentang Kepailitan dan penundaan kewajiban pembayaran utang ("UU Kepailitan") dapat diartikan sebagai sita umum atas semua kekayaan debitor yang pengurusan dan pemberesannya dilakukan oleh kurator di bawah pengawasan Hakim Pengawas. Karena kepailitan memberikan akibat hukum dengan disitanya atas semua kekayaan debitor maka jika suatu Perusahaan Asuransi dinyatakan pailit oleh Pengadilan Niaga, Perusahaan Asuransi tersebut tidak dapat melakukan fungsi atau kewajibannya untuk meng-cover ataupun menjadi lembaga yang berperan dalam pelimpahan risiko, sehingga secara otomatis pihak Pemegang Polis (pihak tertanggung) berhenti dalam menjalankan kewajibannya untuk membayarkan premi asuransi kepada pihak Perusahaan Asuransi tersebut (Hartono, 1991).

Pengaruh norma oleh kolaps merupakan kejiadian yang paling tidak diinginkan kepada industri pertanggungan, oleh sebab itu selain pihak Pemegang Polis yang secara otomatis berhenti dalam menjalankan kewajibannya membayar sejumlah premi kepada industri pertanggungan, kapasitas kolaps ini pula selaku norma membuat derjaat penyitaan kepada semua kekayaan industri pertanggungan itu. Pejabat industri pertanggungan yang sudah kolaps belum mempunyai kewewenangan atau tanggungjawab kepada kekayaan industri yang sudah tersedia ditengah penyitaan global dikarenakan derajat kolaps menjatuhkan kepada permusyawarahan dagang oleh sebab itu juru ulas tentunya bisa dipromosikan dengan tujuan mengadakan penyelenggaraan bahkan pembersihan kepada semua kekayaan industri pertanggungan yang kolaps berikut, yang mana tugas kewenangan kurator relatif berat, tugas kurator sendiri adalah melakukan pengurusan pemberesan harta pailit dan dalam menjalankan tugasnya kurator tersebut bersifat independen dengan pihak debitor dan kreditor. Kurator tidak diharuskan memperoleh persetujuan dari atau menyampaikan pemberitahuan terlebih dahulu kepada debitur atau salah satu organ debitur meskipun dalam keadaan biasa (di luar kepailitan) persetujuan atau pemberitahuan tersebut (Syahputra, 2015).

Bagi masyarakat pengguna jasa asuransi (pihak Pemegang Polis atau tertanggung), istilah kepailitan terhadap Perusahaan Asuransi juga ialah suatu judul yang tidak diinginkan. dikarenakan adanya kekhawatiran atas uang yang telah ditanamkan pada wujud insentif belum bisa ditagihkan, tentunya yang sudah masuk masa tenggang ataupun yang sudah berlangsung. Melihat pada ketentuan Pasal 55 Ayat (I) Undang-undang Kepailitan dan PKPU menjelaskan bahwa, setiap kreditor pemegang hak jaminan kebendaan diposisikan dalam kedudukan hu kum yang lebih tinggi didahulukan dalam menerima pembagian harta pailit daripada kreditur lainnya, karena dapat dilihat dari ketentuan pasal tersebut menggaris bawahi bahwasannya penagih ialah pejabat kebebasan agunan suatu barang yang bisa memberikan agunannya seakan-akan belum tercapainya suatu kolaps. Selanjutnya didalam ketentuan Pasal 52 Ayat (1) Undang-undang Perasuransian mengatur ketentuan bahwa, kedudukan Pemegang Polis diposisikan dalam golongan kreditur dengan hak istimewa (preferen) yang tingkatannya lebih tinggi atau didahulukan dalam menerima pembagian harta pailit daripada kreditur lainnya. Pada tahun 2013 lalu salah satu perusahaan asuransi di Indonesia mengalami kebangkrutan, perusahaan tersebut ialah perusahaan asuransi bumi asih jaya. Perusahaan mengalami kebangkrutan dikarenkan memiliki hutang klaim kepada nasabah yang belum dibayar, sehingga men yebabkan izin perusahaan dicabut oleh pemerintah. Dengan dicabutnya izin usaha 
tersebut menyebabkan kerugian kepada pemegang asuransi atau polis di karena perusahaan tidak bisa mengembalikan premi yang telah dibayarkan oleh pemegang polis dan menyebabkan kerugian. Dari fenomena tersebut ingin melakukan penelitian yang bertujuan untuk menelaah kedudukan hukum pemegang polis sebagai kreditur pada Perusahaan Asuransi dan mengungkapkan perlindungan hukum pemegang polis pada perusahaan asuransi yang dinyatakan pailit

\section{METODE PENELITIAN}

Peneliti ini menggunakan tipe penelitian hukum preskriptif. Investigasi norma preskriptif ialah investigasi norma yang menelaah norma tercatat untuk semua pihak, namun belum menelaah pihak bahan-bahan ataupun penerapannya. Selanjutnya strategi persoalan yang diperuntukkan ialah strategi peraturan-peraturan bahkan strategi abstrak. Strategi perturan-peraturan yaitu dimana strategi berikut dijalankan untuk meneliti keseluruhan peraturan-peraturan undang-undang yang saling berkaitan bersamaan persoalan berikut (tema norma yang akan dilawan), selanjutnya strategi abstrak ialah strategi yang meningkat untuk pengelihatan-pengelihatan dan juga ajaran-ajaran yang tumbuh di tengah pengetahuan norma dengan tujuan menjelaskan teori-teori untuk mempersembahkan penjelasan-penjelasan norma, teori norma, ataupun kaidah norma yang seleras dengan persoalan berikut. Sumber data yaitu data primer dan sekunder yang diperoleh melalui cara akumulasi bendabenda norma yang dipakai merupakan cara telaah referensi yakni dengan mengartikan, mempelajari, serta mengklasifikasikan bahan-bahan hukum dari peraturan-peraturan Undang-undang maupun bukubuku yang berselaras bersamaan dengan persoalaan (Soekanto, 2009). bersama menelusuri bentuk ditengah referensi-referensi yang berkaitan derajat pemegang polis pada perusahaan asuransi yang kolaps. Analisis bahan hukum melalui teknik interpretasi yaitu dalam bentuk penggunaan jenis-jenis penafsiran dalam ilmu hu kum seperti penafsiran historic, grainatikal, kontekstual, sistematis, dan lain-lain dan Teknik deskripsi yaitu dalam bentuk uraian apa adanya terhadap suatu kondisi atau posisi dari proposisi-proposisi hukum atau non hukum (Moleong, 2005).

\section{HASIL DAN PEMBAHASAN}

\section{Kedudukan Hukum Pemegang Polis yang Berhak Menerima Pembagian Harta Pailit}

Kreditur berdasarkan ketentuan Undang-undang Kepailitan dan PKPU Pasal 1 Angka 2: penagih ialah individu yang memiliki tunggakan dikarenakan ketentuan atau peratutan-peraturan yang bisa diminta di depan majelis hukum.' Jadi kreditur merupakan pihak yang memiliki piutang kepada pihak lain. Menjadi masalah yuridis yang penting mana kala aset seseorang atau suatu perusahaan tidak mencukupi untuk membayar semua utang-utangnya, sementara jalan untuk restrukturisasi utang lewat proses perdarnaian tidak tercipta. Dalam keadaan seperti ini sektor hukum mempunyai fungsi utama untuk menyelaraskan diantara kepentingan hak dan kedudukan-kedudukan dari masing-masing kreditor tersebut, sehingga tercapai unsur keadilan dengan memberikan setiap Creditor bagian yang sesuai dengan haknya (Fuadi, 2014).

Berkenaan dengan piutang, masing-masing kreditor memiliki pembagian atau pengkualifikasian atas tingkatan hak preferensi, yang mana penggolongan dari kreditor-kreditor tersebut bertujuan untuk menghindari terjadinya ketidakpastian hukum mau pun ketidakadilan bagi tiap-tiap kreditor saat kepailitan terjadi. Dari penggolongan kreditor tersebut dikenal prinsip debt pooling. Prinsip debt pooling merupakan prinsip yang mengatur bagaiinana kekayaan harta pailit harus dibagi di antara para kreditornya. Dalam melakukan pendistribusian aset tersebut, kurator akan berpegang pada prinsip paritas creditoriuin dan prinsip pari passu prorata parte serta pembagian berdasarkan jenis masing-masing kreditor (structured creditors principle). Prinsip paritas creditorium (kesetaraan kedudu kan para kreditor) menentukan para pemohon memiliki kebebasan yang sejenis kepada segala kekayaan barang pengutang. Selanjutnya asas pari passu pro rata parte yang mempunyai arti bahwasannya aset berikut ialah agunan serempak kepada para penagih bahkan akibatnya mesti diberikan dengan seimbang dengan mereka, melainkan apabila dengan para penagih tersebut yang berkaitan dengan peraturan-peraturan mestti diutamakan ditengah memperbolehkan pelunasan tunggakannya. Pembagian piutang dengan prinsip jaminan secara umum mendasarkan pada ketentuan Pasal 1131 KUHPdt yang menyatakan bahwa Segala kebendaan pihak yang terhutang (debitor), baik yang bergerak maupun yang tidak bergerak, baik yang sudah ada mau pun yang baru akan ada di kemudian hari, menjadi tanggungan untuk segala perikatan perseorangan, perlindungan jaminan ini diberikan undang-undang bagi semua kreditor dalam kedudukan yang sama." Jadi dapat 
dijelaskan berdasarkan ketentuan tersebut bahwa, segala harta benda yang dimili ki oleh pihak debitor menjadi tanggungan bagi semua kreditornya. Kemudian diatur pula dalam ketentuan Pasal $1132 \mathrm{~K}$ UHPdt yang menyatakan bahwa Barang-barang itu menjadi jaminan bersama bagi semua kreditur terhadapnya hasil penjualan barang-barang itu dibagi rnenurut pembagian piutang masing making kecuali bila diantara para kreditur itu ada alasan-alasan sah untuk didahulukan.

Dapat dilihat berdasarkan pada ketentuan Pasal 1132 KUHPdt tersebut menganut prinsip paritas creditorium yaitu, tidak ada perbedaan atau prioritas terhadap kreditor tertentu dan prinsip pari passu prorata parte dimana pelunasan piutang atas hasil eksekusi bagi para kreditor dilakukan secara seimbang. Namun, asas tersebut mengenal pengecualian yaitu golongan kreditur yang memegang hak jaminan kebendaan dan golongan Creditor dengan hak istirnewa (berdasarkan UUKPKPU dan perundang- undangan lainnya) dengan menggaris bawahi 'kecuali bila diantara para kreditur itu ada alasan-alasan sah untuk didahulukan', sehingga asas paritas creditoriurn (prinsip-tidak adanya prioritas terhadap kreditor tertentu) hanya berlaku bagi kreditor konkuren saja. Setelah mengenal prinsip jaminan secara umum, maka perlu dibahas lebih lanjut mengenai gambar an secara garis besar tingkatan preferensi kreditor dalam pembagian piutang terhadap harta debitor pailit. Menurut (Hoesoko, 1. D. 2011) Hasil Penjualan harta pailit ditambah hasil penagihan piutang dikurangi biaya pailit dan utang harta pailit merupakan harta yang dapat dibagikan kepada para kreditor yang dimana klasifikasi dari kreditor-kreditor tersebut ialah sebagai berikut:

1. Kreditor dengan Hak lstimewa (Preferred Creditors)

Kreditor Preferen yaitu, kreditor yang mempunyai hak mendahulukan karena sifat piutang oleh Undang-undang. Kreditor preferen merupakan kreditor yang mempunyai hak istimewa, yaitu suatu hak yang oleh undang-undang berikan kepada seorang berpiutang sehingga tingkatnya lebih tinggi dari pada orang berpiutang lainnya, berdasarkan semata- mata sifat piutangnya (Kumara, 2013). Ketentuan kreditur dengan hak istiinewa di atur pada Pasal 1131 dan 1132 KUHPerdata. Dapat diainbil contoh jika suatu Perusahaan dinyatakan pailit oleh Pengadilan Niaga dan perusahaan terkait belu m membayarkan gaji pekerjanya, maka status pekerja pada perusahaan terkait berkedudu kan hukum sebagai kreditor dengan hak istimewa (preferen), yang mana ketentuannya diatur pada Pasal 95 Ayat (4) Undang-Undang Nomor 13 Tahun 2003 tentang Ketenagakerjaan yang menyatakan bahwa Dalam hal perusahaan dinyatakan pailit atau dilikuidasi berdasarkan peraturan perundang undangan yang berlaku, maka upah dan hak-hak lainnya dari pekerja/buruh merupakan utang yang didahulukan pembayarannya". Hahkan dalam perkara pengujian Undang- Undang dengan Nomor Putusan 67/PU U-Xl/20 13 Mahkamah Konstitusi memposisikan pembayaran upah pekerja lebih utama dari semua tagihan, yang bahkan diutamakan dari tagihan negara dan kreditur separatis. Dengan demikian dapat disimpulkan bahwa pekerja merupakan kreditoryang diistimewakan oleh Undang-Undang Ketenagakerjaan karena sifat piutangnya.

2. Kreditor Pemegang Hak Jaminan (Secutred Creditors)

Kreditor pemegang hak merupakan kreditor pemegang hak jaminan kebendaan in rem yang dalam Kitab U ndang-U ndang Hukum Perdita disebut dengan nama gadai dan hipotik Dasar hukum kreditor pemegang hak jaminan (separatis) ketentuannya dapat dilihat pada Pasal 55 Ayat ( I ) Undangundang Kepailitan dan PKPU yang menyatakan bahwa: "Dengan tetap memperhatikan ketentuan sebagaimana dimaksud dalam Pasal 56, Pasal 57, dan Pasal 58, setiap Kreditor pemegang gadai, jaminan fidusial, hak tanggungan, hipotek, atau hak agunan atas kebendaan lainn ya, dapat mengeksekusi hakn ya seolah-olah tidak terjadi kepailitan." Jadi dapat disimpulkan kreditor pemegang hak jaminan (separatis) merupakan kreditor yang memegang hak jaminan kebendaan, dan kreditor ini pada umu mnya bisa dari pihak perorangan, badan hukum berupa bank ataupun pihak lembaga keuangan lainnya.

3. Kreditor Konkuren (Unsecured Creditos)

Kreditor konkuren merupakan kreditor tanpa pemegang hak jaminan kebendaan, serta kreditur yang tidak diistimewakan sehingga tingkatan hak preferensinya ialah rnenduduki urutan terendah dari semua kreditor pemegang hak jaminan (separatis) dan kreditor dengan hak istimewa (preferen) (Natalia, 2019). Kedudukan kreditor ini sangatlah lemah dalam pelunasan piutangnya karena kreditor ini sama sekali tidak memiliki hak jaminan. kebendaan terhadap debitor. Kreditor konkuren diatur dalam pasal 1132 kitab undang-undang hukum perdata. Kreditor konkuren adalah para kreditor dengan hak pari passu dan pro rata, artinya para kreditor secara bersama-sama memperoleh pelunasan (tanpa ada yang didahulukan) yang terhitung berdasarkan pada besarnya piutang masing-making 
dibandingkan terhadap piutang mereka secara keseluruhan harta kekayaan debitor tersebut . Dengan demikian, para kreditor konkuren mempunyai kedudukan yang sama atas pelunasan utang dari harta debitor tanpa ada yang didahulukan.

Ketiga asas berikut di atas sangat berkaitan tentu dalam aspek norma perjanjian bahkan norma agunan ataupun norma kolaps. Belum ditemukannya asas berikut, oleh sebab itu lembaga kolaps dibuatnya belum berfaaedah dikarenakan teori kolpas ialah merupakan lembaga bertujuan membuat pembatalan kepada kekayaan pengutang yang mempunyai banyaknya penagih, dengan tidak diadakannya kolaps menjadikan para pengutang tentu sama-sama bersaing tentunya yang selaku absah ataupun yang selaku belum absah sampai-sampai membuat suatu kedudukan kezaliman tentu kepada pengutang berikut ataupun kepada penagih utamanya penagih yang diterima terakhir sampai-sampai belum memperoleh pemecahan kekayaan pengutang denngan pelunasan pinjaman-pinjaman pengutang.

\section{Perlindungan Hukum Pemegang Polis Pada Perusahaan Asuransi Yang Dinyatakan Pailit}

Dalam rangka perlindungan hukum pihak pemegang polis, hak dan kewajiban pemegang polis diatur dalam Undang-undang Perasuransian telah mengatur adanya lembaga penjaminan polis yang mana tujuan dibentuknya program penjaminan polis ialah untuk menjamin pengernbalian sebagian atau seluruh hak Pemegang Polis, tertanggung, ataupun peserta lain jika sewaktu-waktu Perusahaan Asuransi tersebut dicabut izinnya dan dilikuidasi. Sebelum dana penjaminan polis terealisasi, industri pertanggungan, industri Resuransi, Perusahaan industri yang islami, serta industri pertanggungan yang islami hendaklah membuat uang tanggungan yang sinkron serupa anggaran serta karakter yang sudah diumumkan oleh Otoritas Jasa Keuangan.

Berdasarkan pendapat Sutan Remy Sjahdeini, Pasal-pasal dalam KUHPerdata dalam hal tata pengutamaan para penagih jika belum dipilihkan bahwasannya sesuatu pinjaman ialah kewenangan eksklusif yang berstatus makin keatas ketimbang pinjaman yang mengayomi agar sesuatu keistimewaan pertanggungan oleh sebab itu rangkaiannya adalah:

a. penagih yang mempunyai pinjaman yang diayomi oleh keistimewaan tanggungan.

b. penagih yang mempunyai kesitimewaan yang spesial.

c. penagih pesaing.

Sementara itu menurut beliau, jika suatu keistimewaan yang spesial yang ditujukan perlu dibayar malah duluan daripada para kreditur yang lain tergolong para penagih yang mempunyai keistimewaan tanggungan, oleh sebab itu rangkainnya para penagih, ialah:

a. penagih yang memiliki kesitimewaan yang spesial.

b. penagih yang mempunyai pinjaman yang diayomi oleh keistimewaan tanggungan.

c. penagih pesaing.

\section{SIMPULAN DAN SARAN}

\section{Simpulan}

Berdasarkan hasil analisis data, dapat disimpulkan bahwa Kedudukan hukum dari yang mempunyai mata-mata merupakan ibarat penagih dengan hak istimewa, mempunyai tingkatan yang lumayan keatas dibandingkan dengan penagih pemegang hak jaminan (separatis) dalam hal pailitnya suatu Perusahaan Asuransi, karena Undang-Undang Perasuransian mengistimewakan Pemegang Polis dalam hal menerima pembagian harta pailit suatu Perusahaan Asuransi, terlebih lagi kedudukan hukum Pemegang Polis sebagai kreditur dengan hak istimewa/preferen dapat dilihat dari sifat piutangnya dan sifat hak didahulukannya. Dalam rangka perlindungan hukum pihak Pemegang Polis, Undang- Undang Perasuransian telah mengatur adanya lembaga penjaminan polis yang mana tujuan dibentuknya program penjaminan polis ialah untuk menjamin pengernbalian sebagian atau seluruh hak Pemegang Polis, tertanggung, ataupun peserta lain jika sewaktu-waktu Perusahaan Asuransi tersebut dicabut izinnya dan dilikuidasi. Sebelum dana penjaminan polis terealisasi, industri pertanggungan, industri Resuransi, Perusahaan industri yang islami, serta industri pertanggungan yang islami hendaklah membuat uang tanggungan yang sinkron serupa anggaran serta karakter yang sudah diumumkan oleh Otoritas Jasa Keuangan.

\section{Saran}

Terkait simpulan penelitian di atas, adapun saran yang diberikan yaitu dalam pailit dan dilikuidasinya 
suatu Perusahaan Asuransi diharapkan kurator memperhatikan hak Pemegang Polis dalam mendapatkan pembagian dari harta pailit Perusahaan Asuransi. Karena dibentuknya peraturan Perundang-undangan Nomor 40 Tahun 2014 mengenai pertanggungan ialah salah satunya dengan menimbang, meningkatkan perlindungan bagi Pemegang Polis/tertanggung. Pemerintah juga diharapkan untuk merealisasikan lembaga penjaminan mata-mata bagaikan yang sudah diperintahkan sesuai ketentuan Pasal 53 Ayat (1) peraturan perundang-undangan Nomor 40 Tahun 2014 mengenai pertanggungan, rnengingat sudah lebih dari 3 warsa mulai dikeluarkannya peraturan perundangundangan Nomor 40 Tahun 2014 mengenai pertanggungan lembaga penanggung mata-mata belum juga dibentuk (Pasal 53 Ayat (4) Undang-undang Perasuransian), sehingga Pemerintah terlihat mengabaikan amanat dari Undang-undang Perasuransian itu sendiri. Lembaga penjaminan polis dibentuk agar nantin ya jika suatu Perusahaan Asuransi pailit maka hak-hak yang diiniliki oleh Pemegang Polis dapat diklaim sehingga Pemegang Polis tetap dapat menerima manfaat dari asuransi.

\section{DAFTAR PUSTAKA}

Fuadi, M. (2014). Hukum Pailit dalam Twori hon Pt oktik. Bandung. Citra Adit ya Bakti.

Hartono, S. (1991). Politik Hukum Menuju Satu Sistem HukumnNasional. Bandung. Alumni.

Kumara, F. M. P. (2013). Benturan antara Kreditor Privilege dengan Kreditor Preferen Pemegang Hipotek Kapal Laut Terkait Adanya Force Majeure. Jurnal Perspektif, 18(1), 32-45.

Moleong, L. J. (2005). Metode Penelitian Kualitatif. Remaja Rosdakarya.

Natalia, T. S. (2019). Akibat Hukum Kepailitan Terhadap Kreditor Pemegang Hak Tanggungan dalam Eksekusi Hak Tanggungan. Jurnal Manajemen Dan Bisnis Sriwijaya, 16(3), 153-163.

Novi, M., Njatrijani, R., \& Aminah. (2016). Tanggungjawab Penanggung terhadap Klaim Tertanggung dalam Pelaksanaan Asuransi Marine Hull and Machinery. Law and Justice, 5(2), $1-13$.

Sabrie, H. Y. (2011). Pembayaran Klaim Asuransi Jiwa Akibat Tertanggung Bunuh Diri (Pt Asuransi Jiwa Manulife Indonesia). Yuridika, 26(1), 31-51.

Soekanto, S. (2009). Penelitian Hukum Normatif. Jakarta: PT Raja Grafindo Persada.

Syahputra, A. (2015). Fungsi dan Kedudukanadvokat Sebagai Penegak Hukum dan Penemu Hukum dalam Sistem Peradilan Pidana. Jurnal Hukum PRIORIS, 4(3), 279-302. 